\title{
The Change over Time in Finnish Residents' Attitudes towards Multi-Story Timber Apartment Buildings
}

\author{
Markku Karjalainen and Hüseyin Emre Ilgın *
}

Citation: Karjalainen, M.; Ilgın, H.E. The Change over Time in Finnish Residents' Attitudes towards Multi-Story Timber Apartment Buildings. Sustainability 2021, 13, 5501. https://doi.org/10.3390/su13105501

Academic Editor: Miguel Amado

Received: 20 April 2021

Accepted: 11 May 2021

Published: 14 May 2021

Publisher's Note: MDPI stays neutral with regard to jurisdictional claims in published maps and institutional affiliations.

Copyright: (c) 2021 by the authors. Licensee MDPI, Basel, Switzerland. This article is an open access article distributed under the terms and conditions of the Creative Commons Attribution (CC BY) license (https:// creativecommons.org/licenses/by/ $4.0 /)$.
School of Architecture, Faculty of Built Environment, Tampere University, P.O. Box 600, FI-33014 Tampere, Finland; markku.karjalainen@tuni.fi

* Correspondence: emre.ilgin@tuni.fi

\begin{abstract}
Due to increasing urbanization, the need for sustainable housing, e.g., sustainable timber housing, is increasing in Finland, as in other countries. Understanding residents' perceptions plays a critical role in the transition to sustainable housing as an important part of the forest-based bioeconomy. This study examined the change over time in Finnish residents' attitudes towards multistory timber apartment buildings. To do this, findings from surveys among residents in 1998-1999 and 2017 were compared with each other. Results mainly highlighted that: (1) residents' attitudes towards timber apartment buildings remained positive over time; (2) participants of both surveys were satisfied with functionality of the apartment unit, immediate surroundings of the building, and number of furnishings and appliances; (3) positive perception regarding sound insulation, indoor climate, and coziness did not change over time; (4) dominant preferences to move to detached and one-or-two story terraced houses gradually gave way to two-story housing and apartment buildings; (5) demand for more timber inside the building and more timber apartments continued over time; and (6) while fire and environmental properties were evaluated positively, impact sound insulation was still seen as a problem. These findings will assist in understanding contemporary housing needs and provide a direction to relevant stakeholders for Finnish housing development.
\end{abstract}

Keywords: apartment buildings; timber; Finnish residents; attitude; change

\section{Introduction}

There has been a growing demand for sustainable urban housing due to increased urbanization. In this sense, as pioneering, recyclable, and sustainable technologies, (engineered) wood products play a critical role in mitigating construction industry-based carbon emissions [1-3] for transition to a sustainable bio-based circular economy [4]. However, despite its growing popularity among the construction industry and civil society stakeholders [5], a user-oriented approach based on perception and experience is still lacking in this discussion [6].

From an ecological point of view, it has been found that the use of timber structures contributes to enhanced energy efficiency in both manufacturing and on-site construction, especially when erecting tall buildings (over eight stories) $[1,7,8]$. Similarly, as a rising business in forest-based industries, multi-story (over two stories) timber buildings have the potential to contribute to the bioeconomy [9] with significant ecological and economic life cycle benefits [8,10-12].

Moreover, multi-story timber building development can significantly contribute to meeting the housing need arising from increased urbanization [13]. Particularly for residents and other end-users, multi-story timber buildings, for example, appear to lead to general improvements in living environments that affect the overall comfort of modern design uses [14]. Additionally, the use of timber contributes to the creation of aesthetically pleasing environments and the protection of physical health $[15,16]$.

Like many other countries that have adopted a forest-based bioeconomy, Finland has identified multi-story timber buildings as the most obvious business opportunity 
for a sustainable bioeconomic transition [17]. Due to policy support, multi-story timber buildings had the opportunity to expand in Finland, and this policy-based pressure has contributed to an overall increase in the volume of wood-based materials used in Finnish residential construction [18].

Developing approaches that try to understand people's expectations and experiences is critical to user-centered business strategies to succeed in the bioeconomy [6,19]. However, understanding perceptions and experiences of multiple actors including residents is often lacking in research about housing construction [20-23]. Thus, there is limited understanding of how consumers, users, or residents perceive timber multi-story buildings [24], while understanding these perceptions is a critical issue for decision-making processes [25].

Previous studies concentrated mainly on probing the users' overall perception of timber as a building material, e.g., [25-32]. In terms of the Finnish context, based on the findings by [31], users endorsed environmental, physiological, visual, and well-being features of timber as a construction material. Furthermore, [32] attempted to understand how the homeowners perceived wood before and after living in a timber house for a year. The results of Viholainen's study [32] indicated that wood-related traditions and memories influence consumers' appreciation for the comfort of a timber house, for example.

How residents perceive the wood and wooden apartment building while living in such an apartment building has not been previously studied in the Finnish context. This study aimed to fill this knowledge gap and address research questions about Finnish residents attitudes towards timber as a building material from a multidimensional perspective and its evolution over time between 1998 and 2017. These dimensions include the main factors behind Finnish residents' perception of their current residence, the difference between living in a timber apartment and living in an apartment built with other materials, the most preferred types of residential buildings to move into, their views on ecological and technical (e.g., fire safety and sound insulation) aspects, and their feedback to designers and developers of multi-story timber apartment buildings.

It is believed that the results will provide insights for various public and private decision-makers to design buildings and communications to better meet the information needs of different types of users including residents and greatly enhancing the acceptability and attractiveness of multi-story timber apartment buildings in the Finnish context. In this study, wood or timber refers to engineered timber products, e.g., cross-laminated timber (CLT). Moreover, in this research, 'multi-story' is defined as a building with over two stories, where 'apartment' is a multi-story residential building.

Furthermore, worth mentioning here, 'sustainable timber housing' refers to housing with sustainable timber where timber is harvested responsibly from continuously renewed and well-managed forests without harming the surrounding environment or natural flora and fauna. However, not all timbers used in housing construction may have been obtained in this way. Furthermore, sustainable housing has many benefits, such as durability, low maintenance cost, energy efficiency, and contribution towards climate adaptation and mitigation [33].

The remainder of this research is organized as follows: First, an explanation of the research method used in the study is given. This is followed by findings about the main common highlights of the resident surveys. In Section 4, similarities and differences between the two surveys are provided. Finally, results are presented.

\section{Research Method}

Paper-based questionnaires were conducted between January 1998 and June 1999, and January-April 2017 in the Finnish language. In the 1998-1999 survey [34] (see Appendix A), the residents of seven of Finland's first wooden apartments were selected as the target group. This questionnaire was sent to 242 apartment units. Surveyed multi-story timber apartment buildings were built between the years of 1996 and 1998 and had a height of between 2 and 4 stories. On the other hand, in the 2017 survey [35] (see Appendix B), the questionnaire was sent to 585 apartment units. Surveyed multi-story timber apartment 
buildings were built between the years of 2011 and 2016 and had a height of between 3 and 8 stories. All buildings in the two surveys were located in suburban areas of Finland. The responses were handled anonymously, and no personally identifiable data were collected or used in the analysis stage. The response rate was over 81\% (197 out of 242) in 1998-1999, while it was over $52 \%$ (308 out of 585) in 2017.

The main common highlights of the two surveys were as follows:

(1) In terms of current residence, the surveyed participants were asked to explain their opinions on their current residence in terms of various parameters (e.g., location of the apartment unit in the building, functionality of the apartment unit, and overall appearance and architecture of the building).

(2) In differences between timber and traditional apartment building residence, the respondents were asked how living in a timber apartment building is different from living in a traditional (e.g., stone) apartment.

(3) In the type of building to move into, the surveyed residents were asked what kind of building (e.g., apartment building, 2-story row house, other) they would most like to move into from their current building. Moreover, they were asked which one to choose based on their experience.

(4) Finally, the residents were asked to give feedback to timber apartment designers and developers.

\section{Findings: Similarities and Differences}

\subsection{Residents' Surveys: Overview}

In the 1998-1999 survey, the respondents (>60\%) were predominantly females. Over $60 \%$ of those surveyed were relatively young, i.e., under 40 years of age. Thirty percent of the participants were under the age of 30 . About $70 \%$ of the residents previously lived in an apartment or two-story detached house, and $83 \%$ of them lived in a brick, concrete, or other stone-framed building. On the other hand, in the 2017 survey, most of the respondents $(>69 \%)$ were females. More than half of those surveyed were over the age of 45 and only a fifth were under 30 . About $80 \%$ of the residents lived in existing timber flats for a maximum of two years. Furthermore, of the 308 surveyed people, 304 knew they lived in a timber apartment and 4 did not.

\subsection{Residents' Surveys: Current Residence}

In the 1998-1999 survey, based on statistical data of respondents' opinions on current residence in timber apartment buildings, they were especially satisfied with the following aspects (Figure 1a): functionality of the apartment unit (85\%)—especially those with a balcony, immediate surroundings of the building $(75 \%)$, quality of furnishings and appliances $(70 \%)$, number of furnishings and appliances $(67 \%)$, and functionality of common and auxiliary spaces $(>60 \%)$. On the other hand, in the 2017 survey, participants were particularly satisfied with the following features (Figure 1b): overall appearance and architecture of the building $(84 \%)$, functionality of the apartment unit $(84 \%)$, and location of the apartment unit in the building $(81 \%)$. These parameters were followed by immediate surroundings of the building $(71 \%)$ and number of furnishings and appliances $(70 \%)$. 


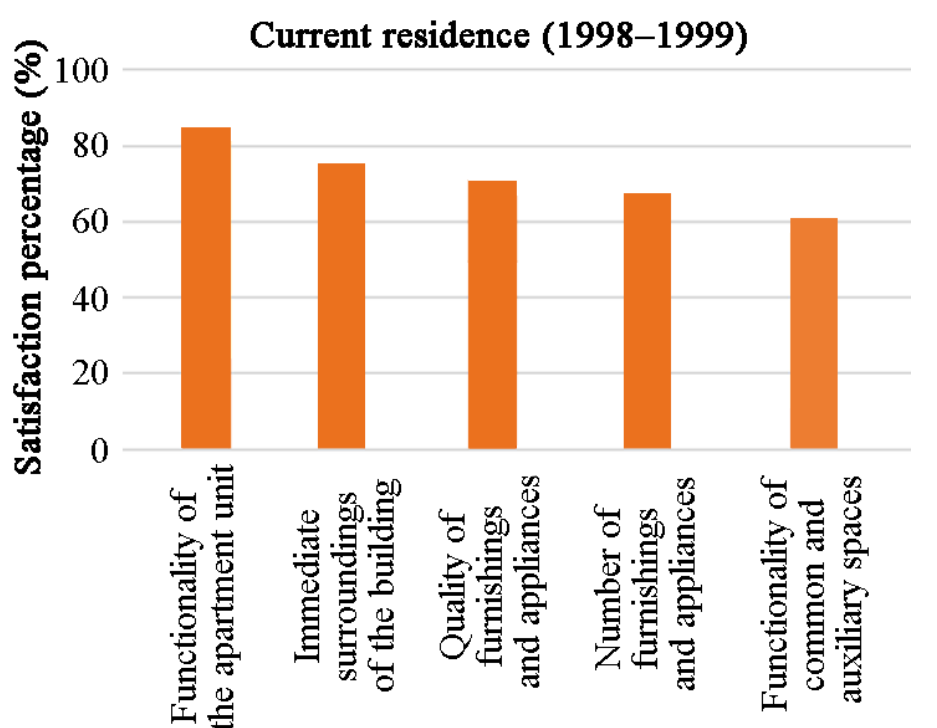

(a)

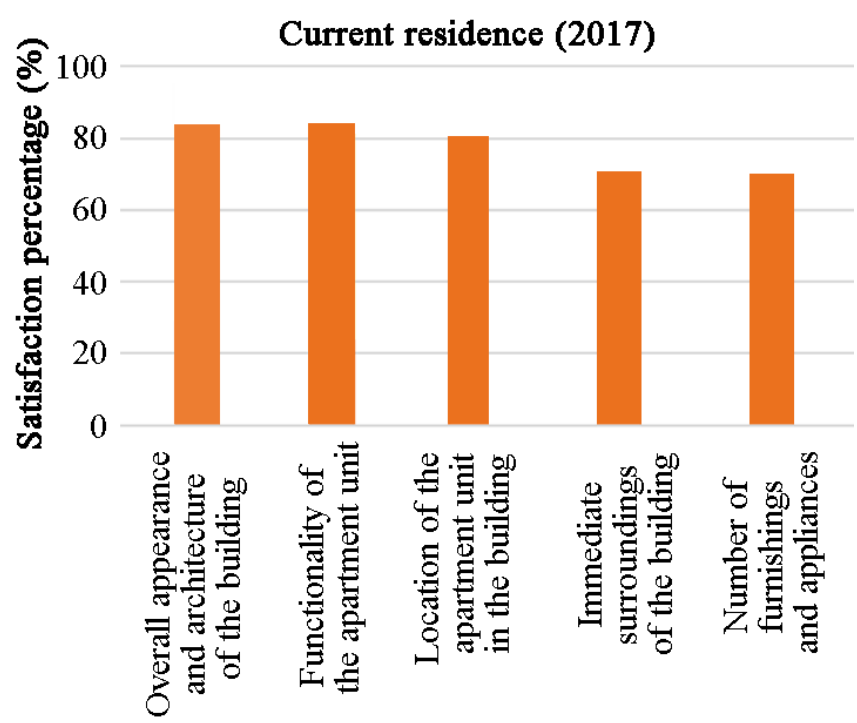

(b)

Figure 1. The most satisfying aspects of current residence: (a) 1998-1999 survey; (b) 2017 survey.

\subsection{Residents' Surveys: Differences between Timber and Traditional Apartment Building Residence}

In 1998-1999, when asked how living in a timber apartment is different from living in a traditional apartment, e.g., stone, the most common responses of the participants were as follows: (1) warm atmosphere and coziness (41 responses), (2) no difference (33 responses), (3) good sound insulation (32 responses), (4) good indoor climate (29 responses), and (5) poor impact sound (sound of footsteps) insulation (16 responses).

Additionally, most $(>50 \%)$ of the respondents perceived timber as a strong and durable building material. Moreover, the vast majority $(>70 \%)$ stated that timber apartments have a nicer appearance and better indoor climate than stone apartments, while it was generally thought that stone apartments are more valuable and long-lasting than timber apartments.

On the other hand, in 2017, in terms of differences between timber and traditional apartment building residence, the most frequent responses of the surveyed residents were as follows: (1) good sound insulation (98 responses), (2) good indoor climate (56 responses), (3) no difference (45 responses), (4) pleasant and beautiful (42 responses), and (5) warm atmosphere and coziness (37 responses).

\subsection{Residents' Surveys: Type of Building to Move into}

In the 1998-1999 survey, when asked what type of building they would like to move to the most, the most common responses were as follows (Figure 2a): (1) detached house $(60 \%),(2)$ one-or-two-story terraced house (27\%), and (3) blocks of flats (13\%). Moreover, when asked which one to choose based on their experience, the most frequent responses of the surveyed residents were as follows: (1) a residence in a timber building (such as an apartment building) $(>50 \%)$, and (2) my choice of residence is not influenced by the building material $(40 \%)$.

On the other hand, in 2017, the most common responses of the participants were as follows (Figure 2b): (1) two-story residential building (38\%), (2) apartment building $(31 \%),(3)$ one-story row house $(22 \%),(4)$ one-story detached house $(21 \%)$, and (5) two-story detached house (14\%). Additionally, when asked which one to choose based on their experience, the most frequent responses of the surveyed residents were as follows: (1) a residence in a timber building (such as an apartment building, row house, detached house) (57\%), and (2) my choice of residence is not influenced by the building material (35\%). 


\section{Type of building to move into (1998-1999)}

\section{0}

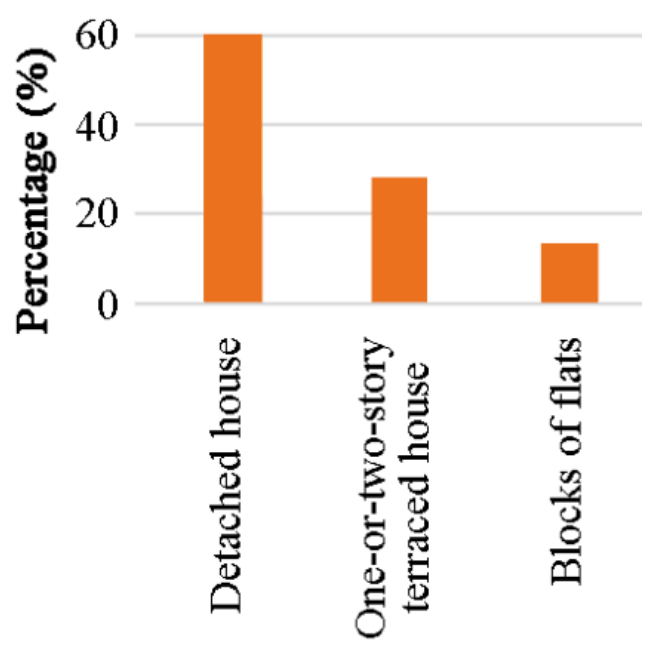

(a)

\section{Type of building to move into} (2017)

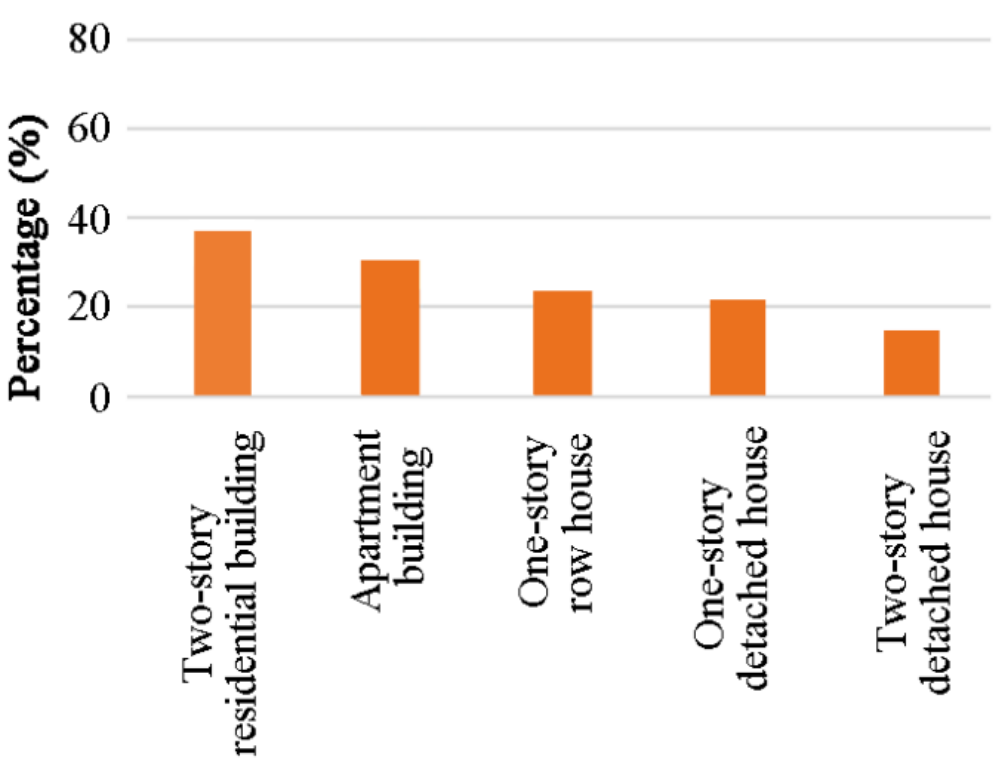

(b)

Figure 2. The most preferred building type to move into: (a) 1998-1999 survey, (b) 2017 survey.

\subsection{Residents' Surveys: Feedback}

In 1998-1999, the respondents were asked to give feedback to designers and developers of multi-story timber apartment buildings. The responses were in the following order of frequency: (1) poor finishing in construction (12 responses), (2) wish for more wood as a visible surface material inside the building (10 responses), and (3) wish for more timber apartment buildings (8 responses).

On the other hand, in 2017, the comments were in the following order of occurrence:

(1) wish for more wood as a visible surface material inside the building (29 responses),

(2) wish for more attention focused on the buildings' sound insulation (25 responses), and

(3) wish for more timber apartment buildings (24 responses).

\section{Discussion}

The findings of the 1998-1999 and 2017 surveys show both similarities, such as current residence, as well as differences, e.g., the type of building to move into, with each other, as detailed below.

In both surveys, respondents generally welcomed timber construction and multistory timber apartment buildings; thus, positive attitudes towards the use of timber in housing have been maintained for nearly two decades. Finland's strong timber building culture [36-38] and increasing recognition of timber as a potential alternative to concrete, especially in multi-story construction [39], may have contributed to sustaining this favorable timber perception over time. Furthermore, the high level of climate and forest policy support to encourage the use of timber in the Finnish construction industry, e.g., [40,41] may have helped to maintain this positive attitude among residents.

Regarding current residence, participants were especially satisfied with functionality of the apartment unit, immediate surroundings of the building, and number of furnishings and appliances in the 1998-1999 and 2017 survey. This might be explained by the fact that considerations regarding furniture, functionality, and the immediate surroundings of the apartments were among the issues that were still emphasized especially in residential architecture and planning in Finland [42,43].

According to the findings of both surveys, good sound insulation, good indoor climate, and warm atmosphere and coziness were assessed among the prominent features of timber 
apartment buildings compared to traditional apartment buildings. Similarly, some recent Finnish surveys, e.g., $[24,31]$ among consumers reported good indoor climate and coziness as advantages of timber housing. Furthermore, research into the improvement of sound insulation of timber residential buildings in Finland for the last two decades, e.g., [44,45] may have contributed to sustaining residents' overall satisfaction with soundproofing issues.

In the 1998-1999 survey, detached and one-or-two-story terraced houses were the most popular types to move into among participants. However, in 2017, the preferences of residents were becoming completely different. Therefore, according to the last survey, approximately two decades later, the two-story housing and apartment buildings were the most preferred types. This recent finding was verified by the findings of the Finnish survey [46] including housing preferences in 2015 that an apartment building (tower block, apartment block, or small-scale apartment block) was the favorite type among respondents. This strong similarity may be an indication that apartment typology can be considered as a general trend of the Finnish timber construction industry. Additionally, in 1998-1999 and 2017 surveys, respondents' housing experiences were similar in terms of their residence in a timber building.

There were common wishes, such as more wood as a visible surface material inside the building, and a wish for more timber apartment buildings among participants of the 1998-1999 and 2017 surveys. This might be a strong indicator that the positive perception towards the use of timber as a construction material in Finland, especially in the residential market, continues today, e.g., $[31,47,48]$.

Furthermore, according to the results of the surveys, it was seen that the complaints of the users about finishing in construction disappeared over time. However, this change may be considered specific to this study rather than a generalization due to several issues such as case-specific results, and the effects of different architects or contractors. On the other hand, unlike 1998-1999, based on the findings of the 2017 survey, residents were generally satisfied with the building's sound insulation performance but stated that the emphasis on this issue should be increased.

Furthermore, worth mentioning here, in both surveys, fire safety, environmental features, e.g., eco-friendliness, and sound insulation regarding impact sounds were among the considerations raised in different ways. In the 1998-1999 survey, timber apartments were rated positively in terms of fire safety. In 2017, most residents reported fire safety of timber apartment buildings was very satisfactory due to the technical measures (i.e., fire alarm system, automatic sprinkler system), similar to the findings from the recent Finnish study conducted in [32].

As a soft value, eco-friendliness was assessed as benefits of timber apartments in the 1998-1999 survey. This finding might be attributed to the finding in the 2017 survey on ecological aspects, which was an effective criterion in residence selection. Similarly, [24] and [31] discussed the environmental benefits of the use of timber in residential construction among consumers in the Finnish context.

In 1998-1999, surveyed participants emphasized that special attention should be paid to impact sound insulation in the intermediate floors. This resembled the findings in the 2017 survey, that according to the residents' views on sound insulation, impact sounds from the apartment unit above were one of the main sources of the most disturbing sounds. This showed that the precautions against impact sounds, e.g., [49-51] were still not taken sufficiently in multi-story timber apartment buildings. 


\section{Conclusions}

This comparative study aimed to provide an overview of the change in Finnish residents' perceptions of multi-story timber apartment buildings between 1998 and 2017. In doing so, this research sought to identify key factors for their perception of their current residence, the difference between living in a timber apartment and living in an apartment built with other materials, the most preferred types of residential buildings to move into, their views on ecological and technical (e.g., fire safety and sound insulation) aspects, and their feedback to designers and developers of multi-story timber apartment buildings.

Positive perception among residents regarding the use of timber in apartment buildings has recently been maintained. The considerations related to functionality of the apartment unit, immediate surroundings of the building, and number of furnishings and appliances were the parameters that were still welcomed by residents for nearly two decades. The attributes regarding sound insulation, indoor climate, and coziness were assessed as the benefits of timber apartment buildings over traditional ones in both surveys. The trend towards more wood as a visible surface material inside the building and more multi-story timber apartment buildings continued over time. However, housing preferences among surveyed residents had changed drastically in recent times and have evolved towards the two-story housing and apartment buildings. While fire safety and environmental properties were positively stated in both studies, impact sound insulation was still seen as a problem.

Overall, the findings of this comparative study can help to create projections for the future by revealing transformation of residents' perceptions of living in timber apartments over time. This can be used as an introductory design guide to timber house planning, especially for architects and developers. In this way, a deeper understanding of the housing prospects of future generations can be developed to create more user-oriented business models in Finnish residential construction.

Author Contributions: Conceptualization, M.K. and H.E.I.; methodology, M.K. and H.E.I.; formal analysis, M.K. and H.E.I.; investigation, M.K. and H.E.I.; data curation, M.K. and H.E.I.; writingoriginal draft preparation, H.E.I.; writing—review and editing, M.K. and H.E.I.; visualization, H.E.I.; supervision, M.K. and H.E.I.; project administration, M.K.; funding acquisition M.K. All authors have read and agreed to the published version of the manuscript.

Funding: This research was funded by Finland's Ministry of the Environment, grant number YM46/612/2016.

Institutional Review Board Statement: Not applicable.

Informed Consent Statement: Not applicable.

Data Availability Statement: Not applicable.

Acknowledgments: The authors express their special thanks to Finland's Ministry of the Environment (YM) for funding this Timber Apartment Building Resident and Developer Survey 2017, and the Riihi Foundation, Puuinfo Oy, Tauno Tönning Foundation, The Finnish Foundation for Technology Promotion, the Foundation for the Promotion of Export Trade in Forest Industry Products, the Support Foundation of the University of Oulu and the Woodworkers' Professional Education Foundation for the grants and encouragement for the 1998-1999 Survey (as a part of Karjalainen doctoral thesis), without which the implementation of this study would not have been possible.

Conflicts of Interest: The authors declare no conflict of interest. 


\section{Appendix A. Survey 1998-1999}

1. Date of response:

2. Respondent's gender: $\quad{ }^{*}$ Female $\quad *$ Male

3. Respondent's age:

4. Size of respondent's household: adults, children ( $<18$ yr.)

5. Apartment unit size: rooms + kitchen/kitchenette + WC-bathroom + balcony/terrace

6. Does your apartment have its sauna?

7. On what floor is your apartment? ${ }^{*}$ Yes floor.

8. Is the building where you live equipped with an elevator? $\quad{ }^{*}$ Yes $\quad{ }^{*}$ No

9. Other information about the apartment (Note! You may choose more than one alternative)

* Apartment is accessed directly by a staircase.

* Apartment is accessible from the corridor.

* Apartment is accessed directly from the ground level.

* Apartment is located at the end of the building.

* Apartment is located on the top floor.

10. How long have you lived in your current residence:

- How do you feel about your current residence? years months.

11. Immediate surroundings of the building

$$
\text { (Very good)/(Good)/(Average)/(Poor)/(Very poor)/(I do not know) }
$$

12. Location of the apartment unit in the building

13. Traffic and parking arrangements on the plot

14. Functionality of the common and auxiliary spaces of the building

15. Functionality of the apartment unit

16. Number of furnishings and appliances

17. Quality of furnishings and appliances

18. Overall quality and finish of the building

19. Overall appearance and architecture of the building Flat:

20. What is better in the current residence than the one you were in before?

21. What is worse in the current residence than the one you were in before?

$$
\text { Apartment building: }
$$

22. What is better in the current residence than the one you were in before?

23. What is worse in the current residence than the one you were in before?

"According to the fire code, all timber apartment buildings over two stories high must be equipped with a fire alarm system and an automatic water or mist sprinkler system."

(Significantly)/(Somewhat)/(Not much)/(Very little)/(Not at all)/(I do not know)

24. How much do you think

a fire alarm system

improves life safety?

25. How much do you think an automatic sprinkler system improves life safety?

26. How much do you think an automatic sprinkler system increases a building's risk of moisture damage? 
27. What do you think about the fire safety of your current residence compared to your previous residence?

28. What do you think about the sound insulation of your current residence compared to your previous residence?

29. What do you think about the lightweight walls of your apartment compared to the stone walls in terms of attaching boards, shelves, and other objects to the walls?

30. What do you think about the thermal insulation of your apartment compared to your previous residence?

31. Do you feel chill in your apartment?

* Significant amount * Some * Just a little * Not at all * I do not know

32. What do you think about your apartment in terms of possible noise disturbances (traffic noise, etc.) in the immediate surroundings?

* Located in a very quiet location * Located in a quiet location * Located in a disturbance-neutral location

* Located in a vulnerable location $\quad *$ Located in a very vulnerable location $\quad *$ I do not know

33. What do you think about your flat in the apartment building in terms of possible noise disturbances (staircase, elevator, corridors)?

${ }^{*}$ Located in a very quiet location ${ }^{*}$ Located in a quiet location ${ }^{*}$ Located in a disturbance-neutral location

* Located in a vulnerable location * Located in a very vulnerable location * I do not know

34. How much disturbingly loud noise can be heard in your apartment from the following sources?

(a) Noise from outside

(Significantly much)/(Much)/(Some)/(Very little)/(None at all)/(I do not know)

(b) Noise from the stairway

(c) Airborne sounds from the next-door apartment

(d) Airborne sounds from the apartments above and below

(e) Impact sounds (of footsteps)

from the apartment above

(f) Knocking/floor impact noises from the apartment above

(g) Noises in the structures

(h) Appliance noise from neighboring apartments

(i) Noises from the neighbor's balcony

(k) Disturbing vibration in the structures

35. Choose the letter of the item in Question 34 (a ... k) whose noise is most disturbing in your current apartment: I think the noise in item is most disturbing.

36. Can you characterize these sounds you find most disturbing in more detail?

* Sounds are low (rumble, thump, bass) * Sounds are high (humming, whining)

* Both high and low sounds occur * I do not know 
37. Do you think the most disturbing noises are caused by your neighbors' style of living or hobbies, i.e., are there factors among your neighbors that may cause more than a normal amount of disturbing noise?

* Child of playing age

* Music lovers

* Noisy domestic animals

* Other?

38. When is the worst noise in your apartment?

(Significantly much)/(Much)/(Some)/(Very little)/(None at all)/(I do not know)

39. How much disturbing noise do you hear from the stairwell?

40. How much disturbing noise do you hear from your neighbor?

41. Are there any harmful bending or vibrations while walking on the floors of your flat?

42. How do you think living in a timber apartment building differs from living in a conventional stone (concrete/brick) apartment building?

43. What do you think about the following statements?

a. Wood is an environmentally friendly material.

(Strongly agree)/(Agree)/(Partially agree)/(Disagree)/(I do not know)

b. Wood is an inexpensive building material.

c. Wood construction skill is high in Finland.

d. Stone houses are often more expensive than wooden houses.

e. Wood is a strong and durable building material.

f. Safety in the event of a fire is better in

a wooden house than in a stone house.

g. A wooden house is more damaged in case of fire than a stone house.

h. By building multi-story timber frame houses, we will achieve more attractive homes.

i. A stone house is longer lasting than a wooden house.

j. A wooden house has a healthier indoor climate than a stone house.

$\mathrm{k}$. Living in a wooden house is more ecological than living in a stone house.

1. Moisture and mold damage are more common in a wooden house than in a stone house.

$\mathrm{m}$. A wooden house is generally more beautiful than a stone house.

n. The use of wood should be increased in Finland.

44. What kind of building did you live in before moving to your current residence?

* Apartment building * Two-story small apartment building * Two-story row house

* One-story row house * Two-story detached house * One-story detached house

45. Describe the main frame material of your residence.

* Mainly wooden frame building * Mainly stone-framed (brick, concrete, etc.) building

* Others * I do not know

46. Describe the main facade material of your residence.

* Mainly wooden frame building * Mainly stone-framed (brick, concrete, etc.) building

* Others * I do not know 
47. Choose the letter of the item in Question $34(\mathrm{a} . . \mathrm{k})$ whose noise is most disturbing in your previous residence: I think the noise in item is most disturbing.

48. If you were to move from this building, into what kind of building would you most preferably want to move?

* Apartment building * Two-story small apartment building * Two-story row house

* One-story row house * Two-story detached house * One-story detached house * Other; where?

49. Which would you choose based on your experience?

* Apartment in a timber building (apartment building, row house, detached house)

* Apartment in a stone building (apartment building, row house, detached house)

* My choice of residence is not influenced by the building material ${ }^{*}$ I do not know

50. Other comments

\section{Appendix B. Survey 2017}

1. Date of response:

2. Respondent's gender: * Female * Male

3. Respondent's age:

4. Size of respondent's household:

adults, children $(<18$ yr.)

5. Apartment unit size: rooms + kitchen/kitchenette + WC-bathroom + balcony/terrace

6. Does your apartment have its own sauna?

*Yes

* No

7. On what floor is your apartment? floor.

8. How long have you lived in your current residence: years months.

9. Have you known that you are living in a timber apartment building?

* Yes ${ }^{*}$ No

10. Assess the significance of the following factors when you chose your current residence

(Very/(Significant)/(Somewhat/(Not very/(Not at all/(I do not significant) significant) significant) significant) know)
(a) Location
(b) Availability
(c) Affordability
(d) Apartment's suitability in your life situation
(e) Functionality of the floor plan
(f) Physical appearance of the building
(g) Use of wood in the building

11. How do you feel about your current residence?

(a) Immediate surroundings of the building

(Very good)/(Good)/(Average)/(Poor)/(Very poor)/(I do not know)

(b) Location of the apartment unit in the building

(c) Traffic and parking arrangements on the plot

(d) Functionality of the common and auxiliary spaces of the building

(e) Functionality of the apartment unit

(f) Number of furnishings and appliances

(g) Quality of furnishings and appliances

(h) Overall quality and finish of the building

(i) Overall appearance and architecture of the building

12. Where would you like wood to be used in timber apartment buildings?

(Note! You may choose more than one alternative)

${ }^{*}$ In the frame of the building ${ }^{*}$ On the facades of the building ${ }^{*}$ In the balconies ${ }^{*}$ In the stairways * On the floors of the apartments ${ }^{*}$ On the walls of the apartments * On the ceilings of the apartments

* In the fixed cabinets of the apartments * In the doors and windows of the apartments * Elsewhere?

“The promotion of timber construction has been justified for ecological reasons. As it grows, one cubic meter of wood binds a ton of carbon dioxide from the atmosphere and through photosynthesis simultaneously releases 700 kilos of oxygen into the atmosphere. Half of the wood's dry weight is carbon. Growing forests are carbon sinks and wood products are carbon stores. Wood is a domestic, renewable, and environmentally friendly construction material. More and more are spoken about environmental issues worldwide." 
13. How do you think the ecological issues described above will influence the choice of residence in the future?

* In your own choice of residence?

(Significantly)/(Somewhat)/(Not much)/(Very little)/(Not at all)/(I do not know)

* Among people generally?

"According to the Finnish fire code, all timber apartment buildings above two stories must be equipped with a fire alarm system and an automatic water or mist sprinkler system."

14. How much do you think

(Significantly)/(Somewhat)/(Not much)/(Very little)/(Not at all)/(I do not know)

a fire alarm system improves

living safety?

15. How much do you think an automatic sprinkler system improves living safety?

16. How much do you think an automatic sprinkler system increases a building's risk of moisture damage?

17. How much disturbingly loud noise can be heard in your apartment from the following sources?

(a) Noise from outside

(Significantly much)/(Much)/(Some)/(Very little)/(None at all)/(I do not know)

(b) Noise from the stairway

(c) Airborne sounds from the next-door apartment

(d) Airborne sounds from the apartments above and below

(e) Sound of footsteps from the apartment above

(f) Knocking/floor impact noises from the apartment above

(g) Noises in the structures

(h) Appliance noise from neighboring apartments

(i) Noises from the neighbor's balcony

(k) Disturbing vibration in the structures

18. Choose the letter of the item in Question $17(\mathrm{a} . . \mathrm{k})$ whose noise is most disturbing in your current apartment: I think the noise in item is most disturbing.

19. Do you think the most disturbing noises are caused by your neighbors' style of living or hobbies, i.e., are there factors among your neighbors that may cause more than a normal amount of disturbing noise?

* Yes; what? * No * I do not know

20. Do you think someone living in an apartment building should generally accept or put up with noises more than in other types of living (detached house, row house)?

* Yes * No * I do not know

21. How do you think living in a timber apartment building differs from living in a conventional (stone/concrete/brick) apartment building?

22. If you were to move from this building, into what kind of building would you most preferably want to move?

* Apartment building * Two-story small apartment building * Two-story row house

* One-story row house * Two-story detached house *One-story detached house * Other; where?

23. Which would you choose based on your experience?

* Apartment in a timber building (apartment building, row house, detached house)

* Apartment in a stone building (apartment building, row house, detached house)

* My choice of residence is not influenced by the building material

* I do not know

24. Other comments and feedback for timber apartment building developers and designers: 


\section{References}

1. Ramage, M.H.; Burridge, H.; Busse-Wicher, M.; Fereday, G.; Reynolds, T.; Shah, D.U.; Wu, G.; Yu, L.; Fleming, P.; Densley-Tingley, D.; et al. The wood from the trees: The use of timber in construction. Renew. Sustain. Energy Rev. 2017, 68, 333-359. [CrossRef]

2. Toppinen, A.; Sauru, M.; Pätäri, S.; Lähtinen, K.; Tuppura, A. Internal and external factors of competitiveness shaping the future of wooden multistorey construction in Finland and Sweden. Constr. Manag. Econ. 2019, 37, 201-216. [CrossRef]

3. Pelli, P.; Lähtinen, K. Servitization and bioeconomy transitions: Insights of prefabricated wooden elements supply networks. J. Clean. Prod. 2020, 224, 1-13. [CrossRef]

4. European Commission. A Sustainable Bioeconomy for Europe: Strengthening the Connection Between Economy, Society and the Environment; Publications Office of the European Union: Luxembourg, 2018.

5. Sposito, C.; Scalisi, F. High-rise timber architecture: An opportunity for the sustainability of the built environment. In PROINNOVATION: Process Production Product; De Giovanni, G., Scalisi, F., Eds.; Palermo University Press: Palermo, Italy, 2019.

6. Toppinen, A.; Autio, M.; Sauru, M.; Berghäll, S. Sustainability-driven new business models in wood construction towards 2030. In Towards a Sustainable Bioeconomy: Principles, Challenges and Perspectives; Leal-Filho, W., Pociovalisteanu, D.M., Borges-de-Brito, P.R., Borges-de-Lima, I., Eds.; Springer: Cham, Switzerland, 2018; pp. 499-516.

7. Van de Kuilen, J.W.G.; Ceccotti, A.; Zhouyan, X.; Minjuan, H. Very tall wooden buildings with cross laminated timber. Procedia Eng. 2011, 14, 1621-1628. [CrossRef]

8. Espinoza, O.; Rodriguez, V.; Mallo, M.F.L.; Buehlman, U. Cross laminated timber: Status and research needs in Europe. Bioresources 2016, 11, 281-295. [CrossRef]

9. Hurmekoski, E.; Jonsson, R.; Korhonen, J.; Jänis, J.; Mäkinen, M.; Leskinen, P.; Hetemäki, L. Diversification of the forest industries: Role of new wood-based products. Can. J. For. Res. 2018, 48, 1417-1432. [CrossRef]

10. Santi, S.; Pierobon, F.; Corradini, G.; Cavalli, R.; Zanetti, M. Massive wood material for sustainable building design: The Massiv-Holz-Mauer wall system. J. Wood Sci. 2016, 62, 416-428. [CrossRef]

11. Lähtinen, K.; Toppinen, A.; Mikkilä, M.; Toivio, M.; Suur-Uski, O. Corporate responsibility reporting in promoting social license to operate in the forestry and sawmilling industries. Forestry 2016, 89, 525-541. [CrossRef]

12. Toppinen, A.; Röhr, A.; Pätäri, S.; Lähtinen, K.; Toivonen, R. Regulation or end-user demand as drivers for sustainability? A Delphi study on the wooden multistory construction in Finland and Sweden towards 2030. J. For. Econ. 2018, 31, 3-10.

13. Dahlbo, H.; Bacher, J.; Lähtinen, K.; Jouttijärvi, T.; Suoheimo, P.; Mattila, T.; Sironen, S.; Myllymaa, T.; Saramäki, K. Construction and demolition waste management-A holistic evaluation of environmental performance. J. Clean. Prod. 2015, 107, 333-341. [CrossRef]

14. Kremer, P.D.; Symmons, M.A. Mass timber construction as an alternative to concrete and steel in the Australian building industry: A PESTEL evaluation of the potential. Int. Wood Prod. J. 2015, 6, 138-147. [CrossRef]

15. Sakuragawa, S.; Miyazaki, Y.; Kaneko, T.; Makita, T. Influence of wood wall panels on physiological and psychological responses. J. Wood Sci. 2005, 51, 136-140. [CrossRef]

16. Rhee, P. Beyond green: Environmental building technologies for social and economic equity. Arch. Des. 2018, 88, 94-101. [CrossRef]

17. Bosman, R.; Rotmans, J. Transition governance towards a bioeconomy: A comparison of Finland and the Netherlands. Sustainability 2016, 8, 1017. [CrossRef]

18. Vihemäki, H.; Ludvig, A.; Toivonen, R.; Toppinen, A.; Weiss, G. Institutional and policy frameworks shaping the Wooden Multi-Storey Construction markets: A comparative case study on Austria and Finland. Wood Mater. Sci. Eng. 2019, 14, 312-324. [CrossRef]

19. Carù, A.; Cova, B. Consuming Experience; Routledge: London, UK, 2007.

20. Geels, F.W. Technological transitions as evolutionary configuration processes: A multi-level perspective and a case-study. Res. Policy 2002, 31, 1257-1274. [CrossRef]

21. McMeekin, A.; Southerton, D. Sustainability transitions and final consumption: Practices and socio-technical systems. Technol. Anal. Strateg. Manag. 2012, 24, 345-361. [CrossRef]

22. Gram-Hanssen, K. Retrofitting owner-occupied housing: Remember the people. Build. Res. Inf. 2014, 42, 393-397. [CrossRef]

23. Geels, F.W.; McMeekin, A.; Mylan, J.; Southerton, D. A critical appraisal of sustainable consumption and production research: The reformist, revolutionary and reconfiguration positions. Glob. Environ. Chang. 2015, 34, 1-12. [CrossRef]

24. Kylkilahti, E.; Berghäll, S.; Autio, M.; Nurminen, J.; Toivonen, R.; Lähtinen, K.; Vihemäki, H.; Franzini, F.; Toppinen, A. A consumer-driven bioeconomy in housing? Combining consumption style with students' perceptions of the use of wood in multi-storey buildings. Ambio 2020, 49, 1943-1957.

25. Høibø, O.; Hansen, E.; Nybakk, E. Building material preferences with a focus on wood in urban housing: Durability and environmental impacts. Can. J. For. Res. 2015, 45, 1617-1627. [CrossRef]

26. Gold, S.; Rubik, F. Consumer attitudes towards timber as a construction material and towards timber frame houses-Selected findings of a representative survey among the German population. J. Clean. Prod. 2009, 17, 303-309. [CrossRef]

27. Hu, Q.; Dewanckera, B.; Zhang, T.; Wongbumru, T. Consumer attitudes towards timber frame houses in China. Procedia Soc. Behav. Sci. 2016, 216, 841-849. [CrossRef]

28. Larasatie, P.; Guerrero, J.; Conroy, K.; Hall, T.; Hansen, E.; Needham, M. What does the public believe about tall wood buildings? An exploratory study in the US Pacific Northwest. J. For. 2018, 116, 429-436. [CrossRef] 
29. Luo, W.; Kanzaki, M.; Matsushita, K. Promoting green buildings: Do Chinese consumers care about green building enhancements? Int. J. Consum. Stud. 2017, 41, 545-557. [CrossRef]

30. Luo, W.; Mineo, K.; Matsushita, K.; Kanzaki, M. Consumer willingness to pay for modern wooden structures: A comparison between China and Japan. For. Policy Econ. 2018, 91, 84-93. [CrossRef]

31. Lähtinen, K.; Harju, C.; Toppinen, A. Consumers' perceptions on the properties of wood affecting their willingness to live in and prejudices against houses made of timber. Wood Mater. Sci. Eng. 2019, 14, 325-331. [CrossRef]

32. Viholainen, N.; Kylkilahti, E.; Autio, M.; Toppinen, A. A home made of wood: Consumer experiences of wooden building materials. Int. J. Consum. Stud. 2020, 44, 542-551. [CrossRef]

33. Sustainable Housing for Sustainable Cities: A Policy Framework for Developing Countries, United Nations Human Settlements Programme (UN-Habitat). 2012. Available online: https:/ / unhabitat.org/sites/default/files/download-manager-files / Sustainable\%20Housing\%20for\%20Sustainable\%20Cities.pdf (accessed on 10 May 2021).

34. Karjalainen, M. The Finnish Multi-Story Timber Apartment Building as a Pioneer in the Development of Timber Construction; University of Oulu: Oulu, Finland, 2002. (In Finnish)

35. Karjalainen, M. Timber Apartment Building Resident and Developer Survey 2017; Final Report; Finland's Ministry of the Environment: Helsinki, Finland; Tampere University: Tampere, Finland, 2017.

36. Riala, M.; Ilola, L. Multi-storey Timber Construction and Bioeconomy-Barriers and Opportunities. Scand. J. For. Res. 2014, 29, 367-377. [CrossRef]

37. Jussila, J.; Lähtinen, K. Effects of institutional practices on delays in construction-Views of Finnish homebuilder families. Hous. Stud. 2019, 35, 1167-1193. [CrossRef]

38. Heikkilä, J. Moisture damage in Finnish wooden houses. J. Build. Apprais. 2005, 1, 331-343. [CrossRef]

39. Lähtinen, K.; Toppinen, A.; Malm, N. Effects of Lobbying Among Urban Planners in Finland—Views on Multi-Storey Wooden Building. Bioprod. Bus. 2019, 4, 77-92.

40. Vihemäki, H.; Toppinen, A.; Toivonen, R. Intermediaries to accelerate the diffusion of wooden multi-storey construction in Finland. Environ. Innov. Soc. Transit. 2020, 36, 433-448. [CrossRef]

41. Ministry of the Environment, Finland. Wood Building Programme. 2021. Available online: https://ym.fi/en/wood-building (accessed on 10 May 2021).

42. Verma, I. Housing Design for All? The Challenges of Ageing in Urban Planning and Housing Design-The Case of Helsinki. Ph.D. Thesis, Department of Architecture, Aalto University, Espoo, Finland, 2019.

43. Ministry of the Environment, Finland. Housing. 2021. Available online: https://ym.fi/en/housing (accessed on 10 May 2021).

44. Sipari, P. Sound Insulation in Timber Buildings: The Finnish Experience. Build. Acoust. 2007, 14, 133-142. [CrossRef]

45. Jäppinen, J.; Pesonen, J. The Acoustics of Structures in Wooden Apartment Building-Case Joensuu Lighthouse. Masters's Thesis, Civil Engineering, Karelia University of Applied Sciences, Joensuu, Finland, 2019.

46. Huttunen, H.; Blomqvist, E.; Ellilä, E.; Hasu, E.; Perämäki, E.; Tervo, A.; Verma, I.; Ullrich, T.; Utriainen, J. The Finnish TOWNHOUSE as a Home. Starting Points and Interpretations. Habitat Components-Townhouse. Final Report. Aalto University Publication Series CROSSOVER. 2016. Available online: https://aaltodoc.aalto.fi/bitstream/handle/123456789/3018 5/isbn9789526071220.pdf? sequence=1\&isAllowed =y (accessed on 10 May 2021).

47. Toppinen, A.; Röhr, A.; Pätäri, S.; Lähtinen, K.; Toivonen, R. The future of wooden multistory construction in the forest bioeconomy-A Delphi study from Finland and Sweden. J. For. Econ. 2018, 31, 3-10. [CrossRef]

48. Häyrinen, L.; Toppinen, A.; Toivonen, R. Finnish young adults' perceptions of the health, well-being and sustainability of wooden interior materials. Scand. J. For. Res. 2020, 35, 394-402. [CrossRef]

49. European Cooperation in Science and Technology (COST) Action TU0901: Integrating and Harmonizing Sound Insulation Aspects in Sustainable Urban Housing Constructions. Building Acoustics throughout Europe Volume 2: Housing and Construction Types Country by Country. 2014. Available online: https://www.cost.eu/wp-content/uploads/2018/07/Part_2.pdf (accessed on 10 May 2021).

50. Rasmussen, B. Building acoustic regulations in Europe-Brief history and actual situation. In Proceedings of the Baltic-Nordic Acoustics Meeting, Reykjavik, Iceland, 15-18 April 2018.

51. Kylliäinen, M.; Saarinen, A. New Finnish building acoustic regulation. In Proceedings of the 23rd International Congress of Acoustics, Aachen, Germany, 9-13 September 2019. 